\title{
Invalid Data
}

National Cancer Institute

\section{Source}

National Cancer Institute. Invalid Data. NCI Thesaurus. Code C50913.

Not valid data. 